\title{
Rethinking value added tax on drinking water supply system: evidence based policy from Indonesia
}

\author{
Haula Rosdiana ${ }^{1,{ }^{*}, \text { Machfud Sidik }}{ }^{2}$, Mainita Hidayati ${ }^{2}$, and Murwendah ${ }^{1}$ \\ ${ }^{1}$ Department of Tax Administration Science, Faculty of Administrative Science, Universitas \\ Indonesia, Indonesia \\ ${ }^{2}$ Research Cluster of Political Taxation, Welfare, and National Resilience (PolTax), Faculty of \\ Administrative Science, Universitas Indonesia, Indonesia
}

\begin{abstract}
Value Added Tax (VAT) for Drinking Water Supply System (DWSS) in Indonesia has not been formulated impartially, holistically and comprehensively by involving related institutions/ ministries. There are disputes that causes a high cost of taxation that discourages the achievement of Millennium Development Goals target. It is notably significant to put the VAT policy on DWSS in the paradigm of national interests and fulfillment of human rights. This study used the paradigm of constructivism with data collection technique through in-depth interviews and Focused Group Discussion (FGD). An evidence based policy was adopted to conduct a better outcome of the study to promote amendment of related VAT regulations. The results of the study indicate an inconsistency between VAT policy and Government Regulations, both Minister of Health Regulations and other Ministries Regulations on Drinking Water Supply System. The impact of the inconsistency was the tax dispute that ultimately causes a high cost of taxation on both sides as well as VAT treatment inconsistency within the drinking water providers (PDAMs) themselves. A practical implication of this study generates the enactment of Government Regulation Number 40/2015 as an amendment of prior regulation concerning VAT exemption on DWSS.
\end{abstract}

\section{Introduction}

Water is an essential part of life as a medium of survival for all living creatures on earth. Thus, the United Nations affirms that the right to water cannot be separated from other human rights. Consequently, to meet the sixth goal of the Sustainable Development Goals (SDGs), i.e. to enhance sanitation and access to drinking water, Indonesia must target the increase of universal and equitable access to safe and affordable drinking water for all in 2030. The United Nations affirms that the fulfillment of SDGs shall secure drinking water and sanitation sustainability, so that people can live healthier and with more dignity.

\footnotetext{
* Corresponding author: h.rosdiana@ui.ac.id
} 
The service provided by PDAM (Regional Water Supply Company) has a significant role since the need of water is mostly provided by PDAM pipes (WHO/UNICEF Joint Monitoring Programme for Water Supply and Sanitation, 2011). The role of PDAM will be more significant since the need of water will increase in accordance with the increase of populations. Unfortunately, the need of water and the important role of PAM (Drinking Water Company) have not acquired proper portion. The development in the sector of drinking water and environmental health has not been the major agenda of the decision makers in Indonesia. The taxation policy, supposedly used as supporting instrument for the development of the state's priority sectors, has not been used optimally. This is seen from the development of taxation policy, particularly VAT policy on the Drinking Water Supply System (DWSS). VAT is a consumption tax levied on each level of delivery of taxable goods or services (multi-stage level) [5]. Pohan states that VAT is essentially a tax imposed on any increase in the value of goods or services in their circulation from producer to consumer [2]. Colbjørnsen defines VAT as a consumption tax aiming to contribute income to the state, in which the tax is levied at each stage of production and distribution having value added [3].

The term "water" used by the Directorate General of Tax was not conformable with one referred to in MDGs goal and by related Ministries (among others the Ministry of Health). Before the enactment of Government Regulation Number 40/2015, the Directorate General of Tax still used the term "clean water". The term seems to refer to the Ministry of Health Regulation No.416/Menkes/PER/IX/1990 that differentiates the meaning of "drinking water" and "clean water". Although, since the issuance of the Ministry of Health Decree No.907/Menkes/SK/VII/2002 on the Terms and Water Quality Monitoring, there has been no differentiation between the term "drinking water" and "clean water"; there is only one term, i.e. drinking water. The implication of inconformity between the term "water" referred to by the Tax Regulation and the Ministry of Health Regulation is the dispute in the taxation practice, particularly in the business process done by PDAM. There is even inequality of taxation treatment by tax examiners due to different interpretations.

Based on the aforementioned background, the study aims to reconstruct VAT policies on DWSS. The research is limited on VAT policies on DWSS in the period of the Law No. 8/1983 to the Law No. 42/2009 and their implementation regulations which have been or are effective up to December 2012.

\section{Methodology}

The research uses the paradigm of constructivism with data collection technique through indepth interviews, Focused Group Discussion (FGD), and participations in the meetings/ discussions done by the Coordinating Ministry of Economic Affairs, Directorate General of Cipta Karya the Ministry of Public Works, as well as Association of Drinking Water Companies in Indonesia (PERPAMSI). An evidence based policy was adopted to conduct a better outcome of the study to promote amendment of related VAT regulations. The research was done by arranging the research steps systematically and structurally, started from making inventory of existing conditions, that includes the strategy of data collection, up to analysis. The result of literary study was then processed to analyze its strengths and weaknesses as well as its consistency with international best practice, and the development of SDGs. Data were analyzed using inductive method since the issue studied is the meaning and understanding of the social phenomena, we can derive the verstehen of the social interaction.

\section{Results and discussions}




\subsection{Implication of the applied VAT policy toward the achievement of SDGs target}

As has been clarified in the background, there is inconsistency between the term "water" used by VAT policies and other related regulations on drinking water supply. This is due to the fact that at the present VAT regulations still use the term "clean water" in accordance with the Ministry of Health Regulation of 1990; whereas since the issuance of the Ministry of Health Decree in 2002, the term, "clean water" is no longer used.

Unfortunately, in the first amendment of Government Regulation (GR) on the VAT exemption on Strategic Goods in 2002 which is Government Regulation No. 43/2002 on the Amendment of the Government Regulation No. 12/2001 on the Import and/or Delivery of Certain Strategic Taxable Goods Exempted from VAT the term used is not altered, even though it is stipulated in the same year with the amendment of the Government Regulation on the VAT exemption on Strategic Goods. This indicates that there is no coordination and synchronization between ministries in formulating the policy on water. Up to the present, even though the Government Regulation on the VAT exemption on Strategic Goods has been amended fourth times, the VAT regulation still uses the term "clean water".

The implication of such terminology inconsistency is potential dispute occurred in the practice of fulfillment of taxation right and obligation. There are some causes of the dispute. First, since in its practice the drinking water service is understood rather partially than comprehensively by some tax examiners, PAM is considered to have obligation to charge Value Added Tax on its service, due to the term "company" in its name i.e. Drinking Water Company. The opinion of the tax examiners is not fully wrong since they just follow the VAT regulation that mention the term "clean water".

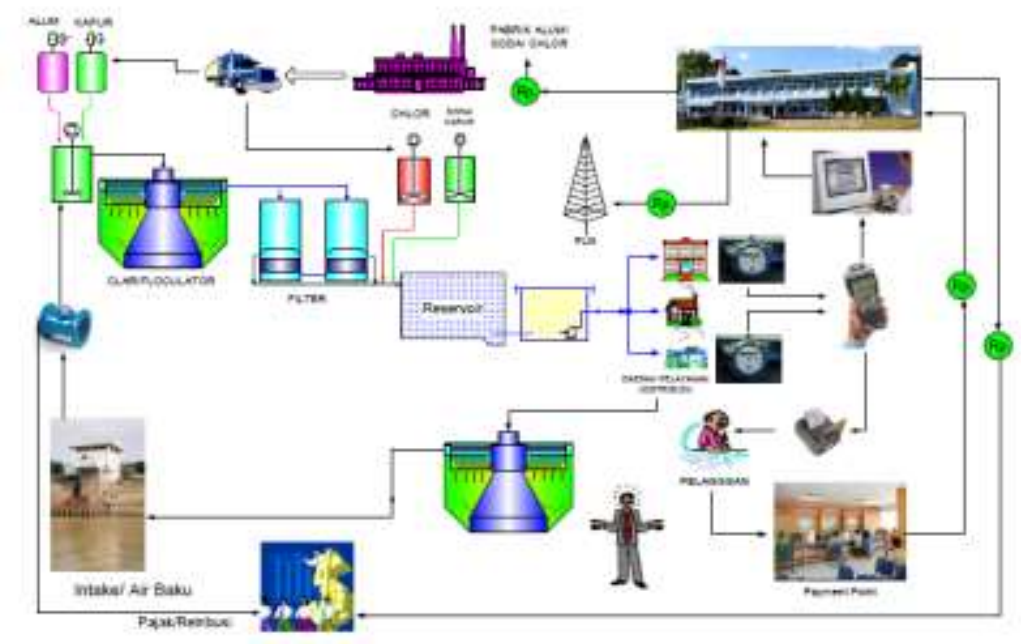

Fig. 1. Business process of piped-distributed drinking water supply and wastewater distribution, PERPAMSI.

Second, since the drinking water service is understood rather partially than comprehensively, some tax examiners also consider that other transactions, related to clean/drinking water service, are also VAT-payable. Those are 1) Water Meter Fee, 2) sewerage retribution, 3) Fee from sewerage installation service, 4) Revenue from new water installation, 5) Revenue from meter rent, 6) Revenue from water reinstallation, and Revenue from persil pipe (a pipe that directly receives wastewater from the source). 
Drinking water is part of DWSS. DWSS consists of several systems, sub-systems, and system-components/elements i.e. raw water source, Water Management System (IPA), transmission system, and distribution system. In the Government Regulation No. 16/2005 it is defined that DWSS is a set of physical/technical and non-physical system of drinking water facilities and infrastructures. Further the Article 14 (1) and (2) mention that raw material protection is done through the integration of DWSS development management and sanitation facilities and infrastructures, consisting of wastewater and garbage facilities and infrastructures.

The implications of VAT dispute are first, the prolonged dispute solving process causes high cost of taxation, thus disturbs the performance of PAM who is supposed to be the government's cutting edge in achieving MDGs target. The result of the literary study shows that some PAMs have been checked several times by the tax authority. The finding and dispute object are centered in a similar problem, although there have been VAT disputes won by PAM, both through 1) the appeal process in Tax Court through Tax Court Decision No. Pu.07928/PP/M.III/16/2006, and 2) the judicial review process in the Supreme Court through the Decision No. 153 B/PK/PJK/2007. In the Supreme Court Decision, the judicial review reapplied by the Director General of Tax is considered of no ground that it should be overruled. However, neither the Tax Court Decision nor Supreme Court Decision is made as jurisprudence. Consequently, similar problem occurs repeatedly. This disturbs PAM's productivity; since there is no certainty in running the business, PAM may at any time be examined by tax authority for the similar case.

Second, the ambiguous VAT treatment causes uncertainty that instills confusion among business actors. This is shown by the many PAMs that apply for private ruling to ask for an explanation about the VAT treatment on their business process. In the "Indonesian Water and Wastewater Forum" held on last 16 January 2013, the participant from PDAM class C (medium class) from East Java stated that due to the tax dispute on drinking water, the Tax Service Office (KPP) issued an Underpaid-Tax Assessment (SKPKB) with the total tax bills of IDR 300 billion, whereas in 2010, the total assets were only IDR $16,713,290,759.24$.

This does not only disturb the financial performance, but may also cause PDAM to stop operating. Another impact is that PDAM is less motivated to improve the quality of its product into safety drinking water. Another participant of the forum even suggested that PDAM change its name into Regional Clean Water Company in order to avoid VATproblem as has been encountered by some PDAMs. This is of course a drawback in achieving MDGs target.

Third, in its practice, the inconsistency of VAT treatment causes uncertainty; there are even VAT-treatment differences among PAMs. This is not in line with the principle of legal certainty in tax collection. Finally, the uncertainty of VAT policies not only produces injustice for certain PAMs, but also for PAM users/customers. In certain region, PAM customers are subject of VAT, while in others are not.

Fourth, VAT is a type of indirect tax, so that the burden of tax can be entirely or partly shifted into other parties. The tax shift can be in the form forward shifting or backward shifting. In reality, forward shifting is more common, thus buyers/customers ultimately bear the burden of tax. Therefore, each addition to tax will ultimately affect the price of product, whereas PAM is bound to the price regulation. PAM, especially PDAM, cannot arbitrarily raise the price, since it is regulated and determined by the Regional Regulation.

\subsection{Reconstruction of VAT policy on DWSS}

The purpose of determining proper drinking water requirements for people's consumption in the Regulation of 1990 and 2002 is to improve the degree of health of 
society; while in the Regulation of 2010 the aim is to hinder water consumed by people from causing an impairment of health. Such aim must be supported by the fiscal policy, both in the form of expenditure policy and tax policy. Tax policy, in this case VAT policy, is an important instrument since the legal character of VAT as indirect tax will affect the cost borne by the customer (society). Moreover, in the WHO/UNICEF report, piped water has an important role and becomes the major aspect of delivering water supply to people.

Apart from becoming the major supplier of water for people, PAM also has the role to achieve sustainable development, since first, the existence of PDAM that embraces the public with good services and affordable price will encourage the change on people's preference, from using ground water to PAM water. Therefore, VAT policy on drinking must be synchronized with Underground Water Tax (PABT) collected by the Regional Government. To preserve our environment, PABT must have a high rate. The preference shift of the people will not occur if PABT is cheaper than PAM water. Thus, if VAT problem is prolonged and disturbs the financial performance of PDAM, the achievement of the policy on affordable water price provision will be more difficult. Second, the business of drinking water supply is not only related to pipes-distributed drinking water but also to wastewater management. This is in line with MDGs i.e. to preserve our environment. Therefore, PDAM empowerment should be perceived as an integral part of the government effort to achieve the national and global development targets. Hence, VAT policy must also be put in similar position.

Besides the two reasons, VAT exemption policy should be given in its entirety to DWSS, hence in line with the Government Regulation No. 16/2005 on the Development of DWSS, regulating that: " 5 . drinking water supply is an activity of providing drinking water to fulfill people's needs as to obtain healthy, clean, and productive life; 6 . drinking water supply system (hereinafter called DWSS) is a set of physical (technical) and non-physical system from the drinking water infrastructures and facilities." Thus, VAT policy should be designed in comprehensive and integrative manner by considering overall DWSS. The giving of VAT exemption comprehensively has become international best practice; it is given not only to water but also to sewerage and drainage services.

We need to consider that conceptually and theoretically there are still debates on whether water (also electricity) is included in the category of goods or services. Therefore in its practice, some countries use the term services to design VAT policy. This is to anticipate any dispute and misinterpretation in its practice, due to partial understanding. Such thing occurs in the VAT dispute cases on DWSS in Indonesia, where the tax examiners collect tax on the service that is part of PDAM activity of supplying drinking water. With legal certainty, VAT policy will not burden society to secure their right to access safety drinking water.

Partial VAT policy on water seems to be discriminative if compared to the VAT treatment on electricity. United Nations has made access to water as Human Rights; yet, instead of improving facility on water, government provides excessive facility on electricity by giving VAT exemption to household with electric power below 6,600 watt. This means, from the perspective of policy priority, there should be some improvements so that VAT policy does not target wrong object, or even cause potential tax losses in the form of deadweight losses/excess burden. The reconstruction of VAT policy on DWSS will ultimately make the role of the state better and the regulating function of the tax instrument is run as it should be.

Another benefit of the reconstruction of integrated VAT policy on DWSS is to reduce national losses. As explained in the background, bad water and sanitation result in the increase of disease and cause Indonesia lose IDR 56 trillion or around 2.3\% from the Gross Regional Domestic Product. The result of study by Ministry of Public Works shows that 
national loss due to bad water and sanitation is as much as a hundred thousand rupiahs per family per month.

\section{Conclusions}

There is inconsistency between VAT policy and Government Regulation, both Minister of Health Regulation and other Ministries Regulations on Drinking Water Supply System. The impact of the inconsistency is the tax dispute that ultimately causes a high cost of taxation on both sides. Another benefit of integrated VAT policy on DWSS is to reduce national loss and people's burden. As an indirect tax, VAT has the characteristic of shifting forward, thus VAT implementation may add to consumer's burden of cost. If VAT policy on DWSS is not immediately revised, there will be disincentive and de-motivation of PDAM in improving the quality of their product from clean water into safety and healthy drinking water as targeted by MDGs.

Based on the above conclusion, it is recommended that the government immediately synchronize VAT policy on water with Minister of Health Regulation No. 492/Menkes/Per/IV/2010 on the Requirements of Drinking Water Quality, and with Government Regulation No. 16/2005 on the Development of DWSS. VAT policy on DWSS should be designed in comprehensive and integrated manners to avoid a high cost of taxation that ultimately overburden society and the operational performance of drinking water providers, as well as disturb the achievement of development target, already planned by the government. Therefore, it is notably important to put VAT policy on DWSS in the paradigm of national interests, human rights fulfillment, and the development of dignified Indonesian people. The improvement of VAT policy on DWSS will also fulfill the mandate of Law No. 42/2009 i.e. to ensure the availability of clean water, needed by society. A practical implication of this study generates the enactment of Government Regulation Number 40/2015 concerning VAT exemption on DWSS.

\section{References}

1. K. Biswas, C. Tortajada, International Journal of Water Resources Development (2010)

2. C.A. Pohan, Complete Guidelines for Value Added Tax (PT Gramedia Pustaka Utama, Jakarta, 2016)

3. Colbjørnsen, International Journal of Cultural Policy 21, 3, 326-343 (2015)

4. Ernst \& Young, The 2011 Worldwide VAT, GST And Sales Tax Guide (Ernst \& Young, 2011)

5. Gunadi, Comprehensive VAT Guide (Jakarta, PT Multi Utama Consultindo, 2011)

6. H. Rosdiana, S.I. Edi, Introduction on Taxation: Policy and Its Implementation in Indonesia (Rajawali Press, Jakarta, 2012)

7. National Development Planning Agency (BAPPENAS), Report on the Achievement of the Millennium Development Goals in Indonesia (2010)

8. P.B. Musgrave, R.A. Musgrave, Public Finance in Theory and Practice (McGraw Hill Company, New York, 1989)

9. Tax Incentives and Foreign Direct Investment: A Global Survey, United Nations Conference On Trade And Development: Geneva. ASIT Advisory Studies No.16, UNCTAD/ITE/IPC/Misc.3. Newyork and Geneva (2000) 